\title{
Tinjauan Kritis terhadap Ontologi Ilmu (Hakikat
Realitas) dalam Perspektif Sains Modern
}

\author{
Ace Nurasa ${ }^{1}$, Nanat Fatah Natsir ${ }^{2}$, Erni Haryanti ${ }^{3}$ \\ 1,2,3Universitas Islam Negeri Sunan Gunung Djati Bandung, Indonesia \\ E-mail: acenurasa@gmail.com,nanatfatahnatsir@uinsgd.ac.id, erni hk@uinsgd.ac.id
}

\begin{abstract}
Article Info
Article History

Received: 2021-11-20

Revised: 2021-12-15

Published: 2022-01-07

Abstract

This study describes a critical review of the ontology of science (the nature of reality) in the perspective of modern science. Ontology studies what objects are studied by science, their manifestations and their relationship to human perception, so that they can produce knowledge. The method used in this study uses a library research method or approach, that library research can be interpreted as a series of activities related to

Keywords: Ontology; The Nature of Reality; Modern Science. the methods of collecting library data, reading and taking notes and processing research materials. The results of this study indicate that the discussion of ontology does not cover the processes, procedures and benefits of an object studied by science, but rather its embodiment. Scientific ontology is a science that studies the nature of science, including modern science, the structure of science and the characteristics of science. The nature of science answers the question of what science really is, the structure of science describes the branches of science, and the characteristics of science explain the character or characteristics of science according to experts.
\end{abstract}

\begin{tabular}{l}
\hline Artikel Info \\
\hline Sejarah Artikel \\
Diterima: $2021-11-20$ \\
Direvisi: 2021-12-15 \\
Dipublikasi: $2022-01-07$
\end{tabular}

Kata kunci: Ontologi; Hakikat Realitas; Sains Modern.

\begin{abstract}
Abstrak
Penelitian ini menjelaskan tentang tinjauan kritis terhadap ontologi ilmu (hakikat realitas) dalam perspektif sains modern. Ontologi mempelajari tentang objek apa yang ditelaah ilmu, perwujudannya dan hubungannya dengan daya tangkap manusia, sehingga dapat menghasilkan ilmu pengetahuan. Metode yang digunakan dalam kajian ini menggunakan metode atau pendekatan kepustakaan (library research), bahwa studi pustaka atau kepustakaan dapat diartikan sebagai serangkaian kegiatan yang berkenaan dengan metode pengumpulan data pustaka, membaca dan mencatat serta mengolah bahan penelitian. Hasil penelitian ini menunjukkan bahwa pembahasan ontologi tidak mencakup pada proses, prosedur dan manfaat dari suatu objek yang ditelaah ilmu, tetapi lebih kepada perwujudannya. Ontologi sains merupakan sebuah ilmu yang mempelajari tentang hakikat sains, termasuk sains modern, struktur sains dan karakteristik sains. Hakikat sains menjawab pertanyaan apa sains itu sebenarnya, struktur sains menjelaskan tentang cabang-cabang sains, dan karakteristik sains menjelaskan tentang karakter atau ciri dari sains menurut para ahli.
\end{abstract}

\section{PENDAHULUAN}

Ontologi merupakan salah satu kajian filsafat. Sebagai cabang filsafat, ontologi bertujuan menginvestigasi dan mengabstraksikan hakikat realitas paripurna yang bersifat tunggal, absolut dan abadi. Studi tersebut membahas keberadaan sesuatu yang bersifat konkret. Menurut (Irwansyah, 2021) bahwa ontologi membahas realitas atau suatu entitas dengan apa adanya. Pembahasan mengenai ontologi berarti membahas kebenaran suatu fakta. Untuk mendapatkan kebenaran itu, ontologi memerlukan proses bagaimana realitas tersebut dapat diakui kebenarannya. Untuk itu proses tersebut memerlukan dasar pola berfikir, dan pola berfikir didasarkan pada bagaimana ilmu pengetahuan digunakan sebagai dasar pembahasan realitas, Ontologi membahas tentang yang ada, yang tidak terikat oleh satu perwujudan tertentu. Sementara, dalam kaitan dengan ilmu, aspek ontologis mempertanyakan tentang objek yang ditelaah oleh ilmu. Secara ontologis ilmu membatasi lingkup penelaahan keilmuannya hanya pada daerah yang berada dalam jangkauan pengalaman manusia dan terbatas pada hal yang sesuai dengan akal manusia. Ontologi membahas tentang pemikiran semesta universal. Menurut (Arifudin, 2020) bahwa ontologi berupaya mencari inti yang termuat dalam setiap kenyataan.

Dalam rumusan Lorens Bagus dalam (Hasbi, 2021) bahwa ontology menjelaskan yang ada yang meliputi semua realitas dalam semua bentuknya. Pengetahuan adalah persepsi subyek (manusia) terhadap obyek (riil dan gaib) atau fakta. Ilmu Pengetahuan adalah kumpulan pengetahuan yang benar disusun dengan sistem dan metode untuk mencapai tujuan yang berlaku universal dan dapat diuji/diverifikasi kebenaran- 
nya. Ilmu Pengetahuan tidak hanya satu, melainkan banyak (plural) bersifat terbuka (dapat dikritik) berkaitan dalam memecahkan masalah. Filsafat Ilmu Pengetahuan mempelajari esensi atau hakikat ilmu pengetahuan tertentu secara rasional. Menurut (Suwardi, 2017) bahwa filsafat ilmu adalah cabang filsafat yang mempelajari teori pembagian ilmu, metode yang digunakan dalam ilmu, tentang dasar kepastian dan jenis keterangan yang berkaitan dengan kebenaran ilmu tertentu. Menurut (Husen, 2017) Filsafat ilmu Pengetahuan disebut juga Kritik Ilmu, karena historis kelahirannya disebabkan oleh rasionalisasi dan otonomisasi dalam mengkritik dogma-dogma dan tahayul. Ilmu tidak dapat tumbuh dengan baik tanpa kritik dari filsafat.

Perkembangan ilmu pengetahuan semakin lama semakin maju dengan munculnya ilmu-ilmu baru yang pada akhirnya memunculkan pula subsub ilmu pengetahuan baru bahkan kearah ilmu pengetahuan yang lebih khusus lagi seperti spesialisasi-spesialisasi (Bairizki, 2021). Secara singkat dapat dikatakan Filsafat adalah refleksi kritis yang radikal. Refleksi adalah upaya memperoleh pengetahuan yang mendasar atau unsur-unsur yang hakiki atau inti. Apabila ilmu pengetahuan mengumpulkan data empiris atau data fisis melalui observasi atau eksperimen, kemudian dianalisis agar dapat ditemukan hukum-hukumnya yang bersifat universal. Oleh filsafat hukum-hukum yang bersifat universal tersebut direfleksikan atau dipikir secara kritis dengan tujuan untuk mendapatkan unsur-unsur yang hakiki, sehingga dihasilkan pemahaman yang mendalam.

Kemudian apa perbedaan Ilmu Pengetahuan dengan Filsafat? Apabila ilmu pengetahuan sifatnya taat fakta, objektif dan ilmiah, maka filsafat sifatnya mempertemukan berbagai aspek kehidupan di samping membuka dan memperdalam pengetahuan. Apabila ilmu pengetahuan objeknya dibatasi, misalnya Psikologi objeknya dibatasi pada perilaku manusia saja, filsafat objeknya tidak dibatasi pada satu bidang kajian saja dan objeknya dibahas secara filosofis atau reflektif rasional, karena filsafat mencari apa yang hakikat. Apabila ilmu pengetahuan tujuannya memperoleh data secara rinci untuk menemukan pola-polanya, maka filsafat tujuannya mencari hakiki, untuk itu perlu pembahasan yang mendalam. Apabila ilmu pengetahuannya datanya mendetail dan akurat tetapi tidak mendalam, maka filsafat datanya tidak perlu mendetail dan akurat, karena yang dicari adalah hakekatnya, yang penting data itu dianalisis secara mendalam.

\section{METODE PENELITIAN}

Sesuai dengan karakteristik masalah yang diangkat dalam penelitan ini maka menggunakan Metode Riset kualitatif, yaitu menekankan analisanya pada data deskriptif berupa kata-kata tertulis yang diamati. Pendekatan kualitatif penulis gunakan untuk menganalisis kajian tinjauan kritis terhadap ontologi ilmu (hakikat realitas) dalam perspektif sains modern, maka dengan sendirinya penganalisaan data ini lebih difokuskan pada Penelitian Kepustakaan (Library Resea$r c h$ ), yakni dengan membaca, menelaah dan mengkaji buku-buku dan sumber tulisan yang erat kaitannya dengan masalah yang dibahas. Metode yang digunakan dalam kajian ini menggunakan metode atau pendekatan kepustakaan (library research), menurut Zed dalam (Rahayu, 2020) bahwa studi pustaka atau kepustakaan dapat diartikan sebagai serangkaian kegiatan yang berkenaan dengan metode pengumpulan data pustaka, membaca dan mencatat serta mengolah bahan penelitian.

Jenis penelitian ini adalah penelitian kualitatif. Menurut Ibnu dalam (Nasser, 2021) penelitian kualitatif adalah suatu penelitian yang datanya dinyatakan dalam bentuk verbal dan dianalisis tanpa menggunakan teknik statistik. Berdasarkan beberapa definisi penelitian kualitatif di atas, dapat disimpulkan bahwa penelitian kualitatif adalah suatu penelitian yang datanya dinyatakan dalam bentuk verbal, tidakmenggunakan angka dan analisisnya tanpa menggunakan teknik statistik.

1. Objek Penelitian

Dalam penelitian ini objek penelitian terdiri dari 2 (dua), yaitu objek formal dan objek material (Mayasari, 2021). Objek formal dalam penelitian ini berupa data yaitu data yang berhubungan dengan tinjauan kritis terhadap ontologi ilmu (hakikat realitas) dalam perspektif sains modern. Sedangkan objek materialnya berupa sumber data, dalam hal ini adalah tinjauan kritis terhadap ontologi ilmu (hakikat realitas) dalam perspektif sains modern.

2. Waktu Penelitian

Penelitian ini dilaksanakan pada bulan November sampai dengan Desember tahun 2021.

3. Teknik Pengumpulan Data

Pengumpulan data yang dilakukan dengan menggunakan teknik dokumentasi yaitu men- 
gadakan survey bahan kepustakaan untuk mengumpulkan bahan-bahan, dan studi literatur yakni mempelajari bahan-bahan yang berkaitan dengan objek penelitian. Teknik pengumpulan data menurut (Bahri, 2021) mengemukakan bahwa merupakan langkah yang paling strategis dalam penelitian karena tujuan untama dari penelitian adalah mendapatkan data. Terdapat beberapa cara atau teknik dalam mengumpulkan data, diantaranya adalah observasi dan dokumentasi. Sumber data yang digunakan dalam penelitian ini mencakup data primer dan sekunder. Menurut (Hanafiah, 2021) bahwa data primer adalah data yang dikumpulkan langsung dari individu-individu yang diselidiki atau data tangan pertama. Sedangkan data sekunder adalah data yang ada dalam pustaka-pustaka. Data primer dalam penelitian ini adalah buku-buku terkait tinjauan kritis terhadap ontologi ilmu (hakikat realitas) dalam perspektif sains modern, dan data sekunder didapatkan dari jurnal-jurnal baik nasional maupun internasional.

4. Alat Pengumpulan Data

Dalam penelitian ini, penulis akan menggunakan metode dokumentasi sebagai alat untuk pengumpul data karena penelitian ini adalah penelitian kepustakaan. Dengan kata lain, menurut (Arifudin, 2021) bahwa teknik ini digunakan untuk menghimpun data-data dari sumber primer maupun sekunder.

5. Teknik Analisis Data

Analisis data tidak saja dilakukan setelah data terkumpul, tetapi sejak tahap pengumpulan data proses analisis telah dilakukan. Penulis menggunakan strategi analisis "kualitatif", strategi ini dimaksudkan bahwa analisis bertolak dari data-data dan bermuara pada kesimpulan-kesimpulan umum. Berdasarkan pada strategi analisis data ini, dalam rangka membentuk kesimpulan-kesimpulan umum analisis dapat dilakukan menggunakan kerangka pikir "induktif". Menurut (Sugiyono, 2015) bahwa metode pembahasan menggunakan metode deskriptif-analisis, yaitu menjelaskan serta mengelaborasi ide-ide utama yang berkenaan dengan topik yang dibahas. Kemudian menyajikannya secara kritis melalui sumber-sumber pustaka primer maupun skunder yang berkaitan dengan tema.

6. Prosedur Penelitian

Data pada penelitian ini dicatat, dipilih dan kemudian diklasifikasikan sesuai dengan kategori yang ada. Pendekatan yang diguna- kan adalah pendekatan deskriptif analitis. Menurut (Na'im, 2021) bahwa deskriptif analitis (descriptive of analyze research), yaitu pencarian berupa fakta, hasil dari ide pemikiran seseorang melalui cara mencari, menganalisis, membuat interpretasi serta melakukan generalisasi terhadap hasil penelitian yang dilakukan. Prosedur penelitian ini adalah untuk menghasilkan data deskriptif yang berupa data tertulis setelah melakukan analisis pemikiran (content analyze) dari suatu teks. Setelah penulis mengumpulkan bahan-bahan yang berhubungan dengan masalah yang akan di bahas dalam penelitian ini, kemudian penulis menganalisis dan menarasikan untuk diambil kesimpulan.

\section{HASIL DAN PEMBAHASAN}

Dalam pembahasan ini akan dibahas tentang pengertian ontologi secara umum, pengertian ontologi menurut para ahli, aliran-aliran ontologi dalam filsafat ilmu, aspek-aspek ontologi ilmu pengetahuan, manfaat ontologi dan ontologi dibidang ilmu pengetahuan alam.

1. Pengertian Ontologi Secara Umum

Ontologi berasal dari bahasa Yunani on atau ontos yang berarti ada (being) dan kata logos yang berarti ilmu (logic), atau ilmu tentang ada sebagaimana adanya secara integral dengan segala aspeknya ontologi merupakan ilmu tentang yang ada. Ontologi adalah ilmu yang membahas tentang hakikat yang ada, yang merupakan ultimate reality baik yang berbentuk jasmani/konkret maupun rohani/abstrak. Kata ontology berarti gagasan tentang kejadian yang paling murni dari ilmu pengetahuan yang menginvestigasi terhadap alam semesta. Sebuah ontology memberikan pengertian untuk penjelasan secara eksplisit dari konsep terhadap repressenttasi pengetahuan pada sebuah knowledge base. Sebuah ontologi juga dapat diartikan sebuah struktur hirarki dari istilah untuk menjelaskan sebuah domain yang dapat digunakan sebagai landasan untuk sebuah knowledge base, dengan demikian ontologi merupakan suatu teori tentang makna dari suatu objek, property dari suatu objek, serta relasi objek tersebut yang mungkin terjadi pada suatu domain pengetahuan. Berdasarkan hal tersebut dapat disimpulkan pada tinjauan filsafat ontologi merupakan studi tentang sesuatu yang ada. 
2. Pengertian Ontologi Menurut Para Ahli

Terdapat beberapa pengertian ontologi menurut para tokoh-tokoh filsafat diantaranya, yaitu:

a) Menurut Suriasumantri (1985)

Ontologi filsafat ilmu membahas tentang apa yang ingin kita ketahui, seberapa jauh kita ingin tahu, atau, dengan kata lain suatu pengkajian mengenai teori tentang "ada". Telaah ontologis akan menjawab pertanyaan-pertanyaan, sebagai berikut, yaitu: a) Apakah obyek ilmu yang akan ditelaah, b) Bagaimana wujud yang hakiki dari obyek tersebut, dan c) Bagaimana hubungan antara obyek tadi dengan daya tangkap manusia (seperti berpikir, merasa, dan mengindera) yang membuahkan pengetahuan (Suriasumantri, 2000).

b) Menurut Soetriono \& Hanafie (2007)

Ontologi yaitu merupakan azas dalam menerapkan batas atau ruang lingkup wujud yang menjadi obyek penelaahan (obyek ontologis atau obyek formal dari pengetahuan) serta penafsiran tentang hakikat realita (metafisika) dari obyek ontologi atau obyek formal tersebut dan dapat merupakan landasan ilmu yang menanyakan apa yang dikaji oleh pengetahuan dan biasanya berkaitan dengan alam kenyataan dan keberadaan (Soetriono, 2007).

c) Menurut Pandangan The Liang Gie

Ontologi adalah bagian dari filsafat dasar yang mengungkap makna dari sebuah eksistensi yang pembahasannya meliputi persoalan-persoalan, yaitu: a) Apakah artinya ada, hal ada?, b) Apakah golongan-golongan dari hal yang ada?, c) Apakah sifat dasar kenyataan dan hal ada?, d) Apakah cara-cara yang berbeda dalam manaentitas dari kategori-kategori logis yang berlainan (misalnya objek-objek fisis, pengertian universal, abstraksi dan bilangan) dapat dikatakan ada?. (Gie, 2010)

d) Menurut Ensiklopedi Britannica Yang juga diangkat dari Konsepsi Aristoteles

Ontologi yaitu teori atau studi tentang wujud seperti karakteristik dasar dari seluruh realitas. Ontologi sinonim dengan metafisika yaitu, studi filosofis untuk menentukan sifat nyata yang asli (real nature) dari suatu benda untuk menentukan arti, struktur dan prinsip benda tersebut (Filosofi ini didefinisikan oleh Aristoteles abad ke-4 SM).
Pengertian paling umum pada ontologi adalah bagian dari bidang filsafat yang mencoba mencari hakikat dari sesuatu. Pengertian ini menjadi melebar dan dikaji secara tersendiri menurut lingkup cabang-cabang keilmuan tersendiri. Pengertian ontologi ini menjadi sangat beragam dan berubah sesuai dengan berjalannya waktu. Menurut (Ekawati, 2017) bahwa ontologi merupakan salah satu di antara lapangan-lapangan penyelidikan kefalsafatan yang paling kuno. Awal mula pikiran Barat yang tertua di antara segenap filsuf Barat yang kita kenal ialah orang Yunani yang bijak dan arif yang bernama Thales. Atas perenungannya terhadap air yang terdapat dimana-mana, ia sempai pada kesimpulan bahwa air merupakan subtansi terdalam yang merupakan asal mula dari segala sesuatu, yang penting bagi kita sesungguhnya bukanlah ajaran-ajarannya yang mengatakan bahwa air itulah asal mula segala sesuatu, melainkan pendiriannya bahwa mungkin sekali segala sesuatu berasal dari satu subtansi belaka. Thales merupakan orang pertama yang berpendirian sangat berbeda di tengah-tengah pandangan umum yang berlaku saat itu.

Disinilah letak pentingnya tokoh tersebut. Kecuali dirinya, semua orang waktu itu memandang segala sesuatu sebagaimana keadaan yang wajar. Apabila mereka menjumpai kayu, besi, air, danging, dan sebagainya, hal-hal tersebut dipandang sebagai subtansisubtansi (yang terdiri sendiri-sendiri). Dengan kata lain, bagi kebanyakan orang tidaklah ada pemeliharaan antara kenampakan (appearance) dangan kenyataan (reality). Beberapa karekteristik ontology seperti diungkapkan oleh Bagus dalam (Ghafir, 2018), antara lain dapat disederhanakan sebagai berikut:

a) Ontologi adalah study tentang arti "ada" dan "berada", tentang ciri-ciri esensial dari yang ada dalam dirinya sendirinya, menurut bentuknya yang paling abstrak.

b) Ontologi adalah cabang filsafat yang mempelajari tata dan struktur realitas dalam arti seluas mungkin, dengan menggunakan katagori-katagori seperti: ada atau menjadi, aktualitas atau potensialitas, nyata atau penampakan, esensi atau eksistensi, kesempurnaan, ruang dan waktu, perubahan, dan sebagainya.

c) Ontologi adalah cabang filsafat yang mencoba melukiskan hakikat terakhir yang ada, yaitu yang satu, yang absolute, bentuk 
abadi, sempurna, dan keberadaan segala sesuatu yang mutlak bergantung kepadanya.

d) Cabang filsafat yang mempelajari tentang status realitas apakah nyata atau semu, apakah pikiran itu nyata, dan sebagainya.

Seperti telah diungkap diatas, hakikat abstrak atau jenis menentukan kesatuan (kesamaan) dari berbagai macam jenis, bentuk dan sifat hal-hal atau barang-barang yang berbeda-beda dan terpisah-pisah. Perbedaan dan keterpisahan dari orang-orang bernama Socrates, Plato, Aristoteles dan sebagainya, terikat dalam satu kesamaan sebagai manusia. Manusia, binatang, tumbuhan, dan bendabenda lain yang berbeda-beda dan terpisahpisah, tersatukan dengan kesamaan jenis sebagai makhluk. Jadi, hakikat jenis dapat dipahami sebagai titik sifat abstrak tertinggi daripada sesuatu hal (an ultimate nature of a thing). Pada titik abstrak tertinggi inilah segala macam perbedaan dan keterpisahan menyatu dalam subtansi dalam filsafat, study mengenai hakikat jenis atau hakikat abstrak ini masuk kedalam bidang metafisika umum (general metaphisics) atau ontology. Oleh sebab itu, pembahasan tentang hakikat jenis ilmu pengetahuan berarti membahas ilmu pengetahuan secara ontologis. Secara ontologis, artinya secara metafisika umum, objek materi yang dipelajari didalam pluralitas ilmu pengetahuan, bersifat monistik pada tingkat yang paling abstrak. Seluruh objek materi pluralitas ilmu pengetahuan, seperti manusia, binatang, tumbuh-tumbuhan dan zat kebendaan berada pada tingkat abstrak tertinggi yaitu dalam kesatuan dan kesamaan sebagai makhluk. Kenyataan itu mendasari dan menentukan kesatuan pluralitas ilmu pengetahuan. Dengan kata lain, pluralitas ilmu pengetahuan berhakikat satu, yaitu dalam kesatuan objek materinya.

Disamping objek materi, keradaan ilmu pengetahuan juga lebih ditentukan oleh objek forma. Objek forma ini sering dipahami sebagai sudut atau titik pandang (point of view), selanjutnya menentukan ruang lingkup study (scope of the study). Berdasarkan ruang lingkup studi inilah selanjutnya ilmu pengetahuan berkembang menjadi plural, berbedabeda dan cenderung saling terpisah antara satu dengan yang lain. Berdasarkan pada objek forma, selanjutnya ilmu pengetahuan cenderung dikembangkan menjadi plural sesuai dengan jumlah dan jenis bagian yang ada didalam objek meteri. Dari objek materi yang sama dapat menimbulkan cabangcabang ilmu pengetahuan yang plural dan berbeda-beda. Dari objek materi manusia, misalnya: melahirkan ilmu sejarah, antropologi, sosiologi, psikologi, dan ilmu pendidikan dengan ranting-rantingnya. Dari objek materi alam, melahirkan ilmu fisika, ilmu kimia, ilmu biologi, dan matematika dengan rantingrantingnya. Jadi secara ontologis, hakikat pluralitas ilmu pengetahuan menurut perbedaan objek forma itu tetap dalam kesatuan system, baik "interdisipliner" maupun "multidisipliner". Interdisipliner artinya keterkaitan antar pluralitas ilmu pengetahuan dalam objek materi yang sama, dan multidisipliner artinya keterkaitan antar pluralitas ilmu pengetahuan dalam objek materi yang berbeda.

Berdasarkan kedua system tersebut, perbedaan antar ilmu pengetahuan justru mendapatkan validitasnya, tetapi secara ontologios pemisahan atas perbedaan ilmu pengetahuan yang berbeda-beda berkonsekuensi negative berupa perilaku disorder (pengrusakan) terhadap realitas kehidupan disamping, pendekatan kuantitatif menurut objek materi dan objek forma terhadap pemecahan masalah hakikat ilmu pengetahuan, secara ontologis masih ada pendekatan kualitatif. Melalui pendekatan kualitatif, persoalan yang sama, yaitu aspek ontology ilmu pengetahuan dengan persoalan hakikat keberadaan pluralitas ilmu pengetahuan, dapat digolongkan kedalam tingkat-tingkat abstrak universal, teoretis potensial dan konkret fungsional Pada tingkat abstrak universal, pluralitas ilmu pengetahuan tidak tampak. Pada tingkat ini yang menampak adalah ilmu pengetahuan itu satu dalam jenis, sifat dan bentuknya didalam ilmu pengetahuan 'filsafat'. Karena filsafat memandang suatu objek materi menurut seluruh segi atau sudut yang ada didalamnya dari keseluruhan segi itulah filsafat mempersoalkan nilai kebenaran hakiki objek materinay, yaitu kebenaran universal yang berlaku bagi semua ilmu pengetahuan yang berbeda dalam jenis, sifat dan dalam bentuk yang bagaimanapun.

Lebih dari itu, bagi filsafat, perbedaan objek materi itu hanyalah bersifat aksidental, bukan substansial. Bagaimanapun perbedaan objek materi, tetap dalam satu system yang tak terpisahkan, yaitu tak terpisahkan dalam substansi mutlak (causa prima). Di dalam causa prima inilah kebenaran universal tertin- 
ggi yang bersifat demikian, maka meliputi pluralitas kebenaran, dan berfungsi sebagai sumber dari segala sumber kebenaran. Selanjutnya, pada tingkat teoreti potencial, pluralitas ilmu pengetahuan mulai tampak. Pada tingkat teoretis, boleh jadi pluralitas ilmu pengetahuan masih berada dalam satu kesatuan system. Suatu teori berlaku bagi banyak jenis ilmu pengetahuan serumpun, tetapi tidak berlaku bagi banyak jenis ilmu pengetahuan yang berlainan rumpun.

Teori ilmu pengetahuan social, cenderung tidak dapat digunakan dalam rumpun ilmu pengetahuan alam, karena perbedaan watak objek materi. Manusia dan masyarakat, sebagai objek materi ilmu pengetahuan social, berpotensi labil dan cenderung berubah-ubah, sedangkan badan-badan benda sebagai objek materi ilmu pengetahuan alam berpotensi stabil dan cenderung tetap. Karena itu, teori ilmu pengetahuan social cenderung berubahubah menurut dinamika eksistensi kehidupan manusia dan masyarakat, dan teori ilmu pengetahuan alam cenderung bersifat tetap. Kemudian, pada tingkat praktis fungsional, pluralitas ilmu pengetahuan justru mendapatkan legalitas akademik. Karena pada tingkat ini, ilmu pengetahuan dituntut untuk memberikan kontribusi praktis secara langsung terhadap upaya reproduksi demi kelangsungan eksistensi kehidupan manusia. Pada tingkat ini, kebenaran teoretis potensial disusun dalam suatu system tekhnologis, sehingga membentuk tekhnologi yang siap memproduksi barang dan jasa sesuai dengan kebutuhan manusia dan masyarakat. Pada tingkat praktis fungsional ini, pluralitas dalam hal perbedaan dan keterpisahan ilmu pengetahuan, tersatukan dalam suatu system tekhnologi, yang semata-mata bertujuan untuk memenuhi kebutuhan demi kelangsungan eksistensi kehidupan.

\section{Aliran-Aliran Ontologi Dalam Filsafat Ilmu}

Dalam mempelajari ontologi muncul beberapa pertanyaan yang kemudian melahirkan aliran-aliran dalam filsafat. Dari masingmasing pertanyaan menimbulkan beberapa sudut pandang mengenai ontologi. Pertanyaan itu berupa "Apakah yang ada itu? (What is being?)", "Bagaimanakah yang ada itu? (How is being?)", dan "Dimanakah yang ada itu? (Where is being?).

a) Apakah yang ada itu? (What is being?)

Dalam memberikan jawaban masalah ini lahir lima filsafat, yaitu sebagai berikut, yaitu:

1) Aliran Monoisme

Aliran ini berpendapat bahwa yang ada itu hanya satu, tidak mungkin dua. Haruslah satu hakikat saja sebagai sumber yang asal, baik yang asal berupa materi ataupun berupa ruhani. Tidak mungkin ada hakikat masing-masing bebas dan berdiri sendiri. Haruslah salah satunya merupakan sumber yang pokok dan dominan menentukan perkembangan yang lainnya. Plato adalah tokoh filsuf yang bisa dikelompokkan dalam aliran ini, karena ia menyatakan bahwa alam ide merupakan kenyataan yang sebenarnya. Istilah monisme oleh Thomas Davidson disebut dengan Block Universe. Paham ini kemudian terbagi ke dalam dua aliran (Suparlan, 2018), yaitu:

a. Aliran Materialisme

Aliran ini menganggap bahwa sumber yang asal itu adalah materi, bukan rohani. Aliran ini sering juga disebut dengan naturalisme. Menurutnya bahwa zat mati merupakan kenyataan dan satu-satunya fakta. Aliran pemikiran ini dipelopori oleh bapak filsafat yaitu Thales (624-546 SM). Ia berpendapat bahwa unsur asal adalah air, karena pentingnya bagi kehidupan. Anaximander (585$528 \mathrm{SM}$ ) berpendapat bahwa unsur asal itu adalah udara, dengan alasan bahwa udara merupakan sumber dari segala kehidupan. Demokritos (460-370 SM) berpendapat bahwa hakikat alam ini merupakan atomatom yang banyak jumlahnya, tak dapat dihitung dan amat halus. Atom-atom itulah yang merupakan asal kejadian alam.

b. Idealisme: Idealisme diambil dari kata "idea" yaitu sesuatu yang hadir dalam jiwa. Aliran ini menganggap bahwa dibalik realitas fisik pasti ada sesuatu yang tidak tampak. Bagi aliran ini, sejatinya sesuatu justru terletak dibalik yang fisik. Ia berada dalam ide-ide, yang fisik bagi aliran ini dianggap hanya merupakan bayang-bayang, sifatnya sementara, dan selalu menipu. Eksistensi benda fisik akan rusak dan tidak akan 
pernah membawa orang pada kebenaran sejati. Dalam perkembangannya, aliran ini ditemui dalam ajaran Plato (428-348 SM) dengan teori idenya. Menurutnya, tiap-tiap yang ada di dalam mesti ada idenya yaitu konsep universal dari tiap sesuatu. Alam nyata yang menempati ruangan ini hanyalah berupa bayangan saja dari alam ide itu.Jadi, idelah yang menjadi hakikat sesuatu, menjadi dasar wujud sesuatu.

2) Aliran Dualisme

Aliran ini berpendapat bahwa benda terdiri dari dua macam hakikat sebagai asal sumbernya, yaitu hakikat materi dan hakikat rohani, benda dan roh, jasad dan spirit. Kedua macam hakikat itu masing-masing bebas dan berdiri sendiri, sama-sama azali dan abadi. Hubungan keduanya menciptakan kehidupan dalam alam ini. Tokoh paham ini adalah Descartes (1596-1650 M) yang dianggap sebagai bapak filsafat modern. Ia menamakan kedua hakikat itu dengan istilah dunia kesadaran (rohani) dan dunia ruang (kebendaan). Ini tercantum dalam bukunya Discours de la Methode (1637) dan Meditations de Prima Philosophia (1641). Dalam bukunya ini pula, Ia menerangkan metodenya yang terkenal dengan Cogito Descartes (metode keraguan Descartes/ Cartesian Doubt). Disamping Descartes, ada juga Benedictus de Spinoza (16321677 M), dan Gitifried Wilhelm von Leibniz (1646-1716 M) (Muslih, 2016).

3) Aliran Pluralisme

Aliran ini berpandangan bahwa segenap macam bentuk merupakan Kenyataan. Pluralisme bertolak dari keseluruhan dan mengakui bahwa segenap macam bentuk itu semuanya nyata. Pluralisme dalam Dictionary of Philosophy and Religion dikatakan sebagai paham yang menyatakan bahwa kenyataan alam ini tersusun dari banyak unsur, lebih dari satu atau dua entitas. Tokoh aliran ini pada masa Yunani Kuno adalah Anaxagoras dan Empedocles, yang menyatakan bahwa substansi yang ada itu terbentuk dan terdiri dari empat unsur, yaitu tanah, air, api, dan udara. Tokoh modern Nurbayani, 'Eksistensi Agama, Ilmu Dan
Filsafat Dalam Mengatasi Persoalan Pendidikan', Jurnal Mimbar Akademika, 2.1 (2017). 12aliran ini adalah William James (1842-1910 M), yang mengemukakan bahwa tiada kebenaran yang mutlak, yang berlaku umum, yang bersifat tetap, yang berdiri sendiri, dan lepas dari akal yang mengenal (Nizar, 2005).

4) Aliran Nihilisme

Nihilisme berasal dari bahasa Latin yang berarti nothing atau tidak ada. Sebuah doktrin yang tidak mengakui validitas alternatif yang positif.Istilah nihilisme diperkenalkan oleh Ivan Turgeniev pada tahun 1862 di Rusia. Doktrin tentang nihilisme sebenarnya sudah ada semenjak zaman Yunani Kuno, yaitu pada pandangan Gorgias (485-360 SM) yang memberikan tiga proposisi tentang realitas. Pertama, tidak ada sesuatupun yang eksis. Kedua, bila sesuatu itu ada, ia tidak dapat diketahui. Ketiga, sekalipun realitas itu dapat kita ketahui, ia tidak akan dapat kita beritahukan kepada orang lain. Tokoh lain aliran ini adalah Friedrich Nietzche (1844-1900 M). Dalam pandangannya dunia terbuka untuk kebebasan dan kreativitas manusia. Mata manusia tidak lagi diarahkan pada suatu dunia di belakang atau di atas dunia di mana ia hidup (Yazdi, 2003).

5) Aliran Agnostisisme

Paham ini mengingkari kesanggupan manusia untuk mengetahui hakikat benda. Baik hakikat materi maupun hakikat ruhani. Kata agnostisisme berasal dari bahasa Grik Agnostos, yang berarti unknown, artinya not, gno artinya know. Timbulnya aliran ini dikarenakan belum dapatnya orang mengenal dan mampu menerangkan secara konkret akan adanya kenyataan yang berdiri sendiri dan dapat kita kenal. Aliran ini dapat kita temui dalam filsafat eksistensi dengan tokohtokohnya seperti, Soren Kierkegaar (1813-1855 M) yang terkenal dengan julukan sebagai Bapak Filsafat Eksistensialisme, yang menyatakan bahwa manusia tidak pernah hidup sebagai suatu aku umum, tetapi sebagai aku individual yang sama sekali unik dan tidak dapat dijabarkan ke dalam sesuatu 
orang lain. Berbeda dengan pendapat Martin Heidegger (1889-Carl W. Ernest, Sufism: An Essential Introduction to the Philosophy and Practice of the Tradition of Islam (USA: Shambhala Publication, 1997). 131976 M), yang mengatakan bahwa satu-satunya yang ada itu ialah manusia, karena hanya manusialah yang dapat memahami dirinya sendiri. Tokoh lainnya adalah, Jean Paul Sartre (19051980 M), yang mengatakan bahwa manusia selalu menyangkal. Hakikat beradanya manusia bukan entre (ada), melainkan a entre (akan atau sedang). Jadi, agnostisisme adalah paham pengingkaran atau penyangkalan terhadap kemampuan manusia mengetahui hakikat benda, baik materi maupun ruhani (Kartanegara, 2002).

b) Bagaimanakah yang ada itu? (How is being?)

Apakah yang ada itu sebagai sesuatu yang tetap, abadi, atau berubah-ubah? Dalam hal ini, Zeno (490-430 SM) menyatakan bahwa sesuatu itu sebenarnya khayalan belaka. Pendapat ini dibantah oleh Bergson dan Russel. Seperti yang dikatakan oleh Whitehead bahwa alam ini dinamis, terus bergerak, dan merupakan struktur peristiwa yang mengalir terus secara kreatif.

c) Dimanakah yang ada itu? (How is being?) Aliran ini berpendapat bahwa yang ada itu berada dalam alam ide, adi kodrati, universal, tetap abadi, dan abstrak. Sementara aliran materilisme berpendapat sebaliknya, bahwa yang ada itu bersifat fisik, kodrati, individual, berubah-ubah, dan riil.

\section{Aspek-Aspek Ontologi Ilmu Pengetahuan}

Ontologi membahas tentang yang ada, yang tidak terikat oleh satu perwujudan tertentu. Dalam kaitan dengan ilmu, aspek ontologis mempertanyakan tentang objek yang ditelaah oleh ilmu. Secara ontologis ilmu membatasi lingkup penelaahan keilmuannya hanya pada daerah yang berada dalam jangkauan pengalaman manusia dan terbatas pada hal yang sesuai dengan akal manusia. Ontologi membahas tentang yang ada yang universal, menampilkan pemikiran semesta universal. Ontologi berupaya mencari inti yang termuat dalam setiap kenyataan. Dalam rumusan Lorens Bagus; ontology menjelaskan yang ada yang meliputi semua realitas dalam semua bentuknya, Ada beberapa aspek ontologis yang perlu diperhatikan dalam ilmu pengetahuan. Menurut (Jalaluddin, 2015) bahwa aspek-aspek ontologis tersebut, yaitu:

a) Metodis

Menggunakan cara ilmiah, berarti dalam proses menemukan dan mengolah pengetahuan menggunakan metode tertentu, tidak serampangan.

b) Sistematis

Saling berkaitan satu sama lain secara teratur dalam suatu keseluruhan. berarti dalam usaha menemukan kebenaran dan menjabarkan pengetahuan yang diperoleh, menggunakan langkah-langkah tertentu yang teratur dan terarah sehingga menjadi suatu keseluruhan yang terpadu.

c) Koheren

Unsur-unsurnya harus bertautan, tidak boleh mengandung uraian yang bertentangan. berarti setiap bagian dari jabaran ilmu pengetahuan itu merupakan rangkaian yang saling terkait dan berkesesuaian (konsisten).

d) Rasional

Harus berdasar pada kaidah berfikir yang benar (logis).

e) Komprehensif

Melihat obyek tidak hanya dari satu sisi/ sudut pandang, melainkan secara multidimensional atau secara keseluruhan (holistik).

f) Radikal

Diuraikan sampai akar persoalannya, atau esensinya.

g) Universal

Muatan kebenarannya sampai tingkat umum yang berlaku di mana saja.

\section{Manfaat Ontologi}

Ontologi yang merupakan salah satu kajian filsafat ilmu mempunyai beberapa manfaat, di antaranya sebagai berikut:

a) Membantu untuk mengembangkan dan mengkritisi berbagai bangunan sistem pemikiran yang ada.

b) Membantu memecahkan masalah pola relasi antar berbagai eksisten dan eksistensi.

c) Bisa mengeksplorasi secara mendalam dan jauh pada berbagai ranah keilmuan maupun masalah, baik itu sains hingga etika (Susanto, 2015). 
Dalam ontologi ditemukan pandanganpandangan pokok pemikiran, yaitu monoisme, dualisme, pluralisme, nihilisme, dan agnosticisme. Monoisme adalah paham yang menganggap bahwa hakikat asalnya sesuatu itu hanyalah satu. Asal sesuatu itu bisa berupa materi (air, udara) maupun ruhani (spirit, ruh). Dualisme adalah aliran yang berpendapat bahwa asal benda terdiri dari dua hakikat (hakikat materi dan ruhani, hakikat benda dan ruh, hakikat jasad dan spirit).

Pluralisme adalah paham yang mengatakan bahwa segala hal merupakan kenyataan. Nihilisme adalah paham yang tidak mengakui validitas alternatif yang positif. Dan agnosticsisme adalah paham yang mengingkari terhadap kemampuan manusia dalam mengetahui hakikat benda.

\section{Ontologi Dibidang Ilmu Pengetahuan Alam}

Menurut (Umar, 2016) bahwa ontologi sains merupakan sebuah ilmu yang mempelajari tentang hakikat sains, struktur sains dan karakteristik sains. ontologi sains adalah ilmu yang mempelajari tentang hakikat dan struktur sains. Sementara, hakikat sains adalah menjelaskan dan menjawab pertanyaan apa sains itu sebenarnya dan yang dikatakan struktur sains adalah menjelaskan tentang cabang-cabang sains, dan karakteristik sains menjelaskan tentang karakter atau ciri dari sains menurut para ahli. Melalui science inilah, pemikiran manusia akhirnya dapat mencapai makna hakiki (meaning) yang pada dasarnya lebih utama daripada kebenaran (truth) karena makna merupakan esensi dan substansi dari berbagai fenomena kehidupan manusia.

a) Hakikat Sains

Hakikat sains ini terdapat dua pengetahuan yang harus kita ketahui yaitu pengetahuan rasional dan pengetahuan empiris. Pengetahuan rasional merupakan sebuah pengetahuan dimana kita harus menguji atau meneliti kebenaran dengan akal. Kita meneliti suatu kejadian dan memberikan suatu kesimpulan sementara atau hipotesis. Hipotesis itu harus berdasarkan rasional, begitu juga dengan penelitian harus berdasarkan rasional dan penelitian itu juga harus berdasarkan sebab akibat.

Contoh : Ada 2 kampung, yaitu kampung A dan kampung B. Di kampung A banyak lahan tanah yang subur, sedangkan di kampung B lahan tanahnya tidak subur.
Diambil kesimpulan bahwa kampung A lahan tanahnya lebih subur dari pada lahan tanah di kiampung B. Lalu dicari tahu tentang sebab akibatnya, ternyata di kampung A, banyak penduduk yang memelihara hewan kambing, dan kotoran dari hewan kambing itu digunakan untuk memupuk lahan tanah mereka sehingga tanah di kampung A menjadi subur, sedangkan di kampung B banyak juga penduduk yang memelihara hewan kambing, akan tetapi kotoran dari hewan kambing tersebut dijual ke kota lain.

Dalam hal ini, hipotesis/dugaan sementara adalah rasional untuk menjadikan tanah yang subur diperlukan pupuk alami yaitu kotoran dari hewan kambing, karena kotoran kambing banyak mengandung zat pupuk nya. Semakin banyak lahan tanbah diberi pupuk alami dari kotoran hewan kambing, semakin subur lahan pertanahan tersebut. Dan hipotesis ini rasional karena adanya hubungan pengaruh atau sebab akibat. Pengetahuan empiris merupakan sebuah pengetahuan dengan menguji hipotesis dengan prosedur metode ilmiah. Hipotesis yang sudah dibahas diatas selanjutnya diajukan bukti yang empiris karena kita mengambil dari dua kampung yang berbeda yaitu kampung A dan kampung B. Dengan menggunakan metode ilmiah dapat kita ambil kesimpulan bahwa kotoran kambing sangat berguna untuk menggemburkan tanah, sehingga tanah akan menjadi subur dan secara otomatis tanaman tanaman juga akan subur.

Berbeda dengan lahan tanah yang tidak di beri pupuk alami dari kotoran kambing, tanah akan menjadi kurang subur. Inilah yang dinamakan pengetahuan empiris yaitu dengan menguji hipotesis atau dugaan sementara menggunakan metode ilmiah atau penelitian. Rumus baku metode ilmiah adalah logico-hypotetico-verificatif (bukti bahwa itu logis, tarik hipotesis dan ajukan bukti empiris). Selanjutnya, puncak pencarian basis ontologis semesta terdapat konvergensi antara agama dan sains yang menempatkan "prinsip cahaya" sebagai basis teorinya. Namun demikian, masingmasing masih menyisakan masalah mendasar. Dalam agama belum dapat menjelaskan bagaimana proses terjadinya alam fisik dari cahaya metafisik. Sebaliknya dalam sains belum dapat menjelaskan dari mana 
asal-usul cahaya (energi) sebelum peristiwa big bang. Landasan normatif yang menyebutkan secara eksplisit realitas cahaya sebagai basis ontologi semesta terdapat dalam hadis yaitu "Cahaya Muhammad" dengan merujuk pada hadis tentang "tanpa Muhammad maka realitas alam tidak akan tercipta.

Asumsi ini benar bila sebab akibat itu memiliki hubungan rasional.Ilmu atau sains berisi tentang teori, teori itu pada dasarnya menerangkan hubungan sebab akibat.Dan sains tidak memberikan nilai baik atau buruk, halal atau haram, sopan atau tidak sopan, indah atau tidak indah, sains hanya memberikan nilai benar atau salah.

b) Struktur sains

Secara garis besar sains dibedakan menjadi dua, yaitu sains kealaman dan sains sosial, yang menjelaskan struktur sains dalam bentuk nama-nama ilmu.

\section{a) Sains Kealaman}

Sains kealaman terdiri dari beberapa bidang, yaitu: 1) Astronomi, 2) Fisika : mekanika, bunyi, cahaya, dan optic, fisika, nuklir, 3) Kimia : kimia organik, kimia teknik, 4) Ilmu bumi : paleontology, ekologi, geofisika, geokimia, mineralogy, geografi, serta 5) Ilmu hayat : biofisika, botani, zoology.

b) Sains Sosial

Sains sosial terdiri dari beberapa bidang, yaitu: 1) Sosiologi: sosiologi komunikasi, sosiologi politik, dan sosiologi pendidikan, 2) Antropologi: antropologi budaya, antropologi ekonomi, 3) Psikologi: psikologi pendidikan, psikologi anak, psikologi abnormal, 4) Ekonomi: ekonomi makro, ekonomi lingkungan, ekonomi pedesaan, serta 5) Politik: politik dalam negeri, politik hukum, politik internasional.

c) Karakteristik sains

Ada beberapa ahli menjelaskan tentang karakteristik dari sains diantaranya Vessel mengemukakan beberapa ciri umum sains, yaitu:

a) Hasil sains bersifat akumulatif dan merupakan milik bersama, artinya hasil sains yang lalu dapat digunakan untuk penyelidikan hal yang baru, dan tidak memonopoli. Setiap orang dapat memanfaatkan hasil penemuan orang lain. b) Hasil sains kebenarannya tidak mutlak dan bisa terjadi kekeliruan karena yang menyelidikinya adalah manusia.

c) Sains bersifat objektif , artinya prosedur kerja atau cara penggunaan metode sains tidak tergantung kepada siapa yang menggunakan, tidak tergantung pada pemahaman secara pribadi.

Selain itu ahli lain yaitu Trowbridge, dkk mengemukakan ciri-ciri sains, yaitu:

a) Bersifat rasional (hasil dari proses berpikir dengan menggunakan rasio atau akal).

b) Bersifat empiris (pengalaman oleh panca indra).

c) Bersifat umum (hasil sains bisa digunakan oleh semua orang tanpa terkecuali).

d) Bersifat akumulatif (hasil sains dapat dipergunakan untuk dijadikan objek penelitian berikutnya).

\section{SIMPULAN DAN SARAN}

\section{A. Simpulan}

Berdasarkan pemaparan pada penelitian ini dapat disimpulkan bahwa ontologi mempelajari tentang objek apa yang ditelaah ilmu, perwujudannya dan hubungannya dengan daya tangkap manusia, sehingga dapat menghasilkan ilmu pengetahuan. Pembahasan ontology tidak mencakup pada proses, prosedur dan manfaat dari suatu objek yang ditelaah ilmu, tetapi lebih kepada perwujudannya. Ontologi sains merupakan sebuah ilmu yang mempelajari tentang hakikat sains, struktur sains dan karakteristik sains. Hakikat sains menjawab pertanyaan apa sains itu sebenarnya, struktur sains menjelaskan tentang cabang-cabang sains, dan karakteristik sains menjelaskan tentang karakter atau ciri dari sains menurut para ahli.

\section{B. Saran}

Pembahasan "Tinjauan Kritis Terhadap Ontologi Ilmu (Hakikat Realitas) Dalam Perspektif Sains Modern" dalam penelitian ini masih sangat terbatas dan membutuhkan banyak masukan. Saran untuk penulis selanjutnya adalah mengkaji lebih dalam tinjauan kritis terhadap ontologi ilmu (hakikat realitas) dalam perspektif sains modern, dan studi kritis terhadap tinjauan kritis terhadap ontologi ilmu (hakikat realitas) dalam perspektif sains modern. 


\section{DAFTAR RUJUKAN}

Arifudin, O. (2020). Psikologi Pendidikan (Tinjauan Teori Dan Praktis). Bandung: Widina Bhakti Persada.

Arifudin, O. (2021). Implementasi Balanced Scorecard dalam Mewujudkan Pendidikan Tinggi World Class. Edumaspul: Jurnal Pendidikan, 5(2), 767-775.

Bahri, A. S. (2021). Pengantar Penelitian Pendidikan (Sebuah Tinjauan Teori dan Praktis). Bandung: Widina Bhakti Persada.

Bairizki, A. (2021). Manajemen Perubahan. Bandung : Widina Bhakti Persada.

Ekawati. (2017). Reorientasi Ontologi, Epistemology Dan Aksiologi Dalam Perkembangan Sains. Jurnal Tarbawiyah Ilmu Pendidikan, 10(2), 75-84.

Ghafir. (2018). Perspektif "Ontologi" Dalam Filsafat Ilmu (Telaah Atas Buku Filsafat Ilmu Tulisan Jujun S. Suriasumantri). Jurnal Wahana Akademika, 5(2), 33-43.

Gie. (2010). Pengantar filsafat ilmu. Yogyakarta: Liberti.

Hanafiah, H. (2021). Pelatihan Software Mendeley Dalam Peningkatan Kualitas Artikel Ilmiah Bagi Mahasiswa. Jurnal Karya Abdi Masyarakat, 5(2), 213-220.

Hasbi, I. (2021). Administrasi Pendidikan (Tinjauan Teori Dan Praktik). Bandung: Widina Bhakti Persada.

Husen. (2017). Ikhtisar Filsafat Ilmu Dalam Perspektif Barat Dan Islam. Yogyakarta: CV. Social Politic Genius.

Irwansyah, R. (2021). Perkembangan Peserta Didik. Bandung : Widina Bhakti Persada.

Jalaluddin. (2015). Filsafat Pendidikan. Jakarta: Raja Grafindo Persada.

Kartanegara. (2002). Panorama Filsafat Islam. Bandung: Mizan.

Mayasari, A. (2021). Implementasi Sistem Informasi Manajemen Akademik Berbasis Teknologi Informasi dalam Meningkatkan Mutu Pelayanan Pembelajaran di SMK. JIIP-
Jurnal Ilmiah Ilmu Pendidikan, 4(5), 340345. https://doi.org/10.54371/jiip.v4i5.277

Muslih. (2016). Filsafat Ilmu, Kajian atas asumsi dasar, paradigma dan kerangka teori ilmu pengetahuan. Yogyakarta: LESFI.

Mustamin. (2019). Filsafat Emanasi Ibnu Sina. Jurnal Pemikiran Konstruktif Bidang Filsafat Dan Dakwah, 16(1), 75-90.

Nasser, A. A. (2021). Sistem Penerimaan Siswa Baru Berbasis Web Dalam Meningkatkan Mutu Siswa Di Era Pandemi. Biormatika: Jurnal Ilmiah Fakultas Keguruan Dan Ilmu Pendidikan, 7(1), 100-109.

Nizar. (2005). Filsafat Pendidikan Islam: pendekatan historis, teoritis dan praktis. Jakarta: Ciputat Press.

Rahayu, Y. N. (2020). Program Linier (Teori Dan Aplikasi). Bandung : Widina Bhakti Persada.

Soetriono. (2007). Filsafat Ilmu dan Metodologi Penelitian. Yogyakarta: Andi Offset.

Sugiyono. (2015). Metode Penelitian Pendidikan (Pendekatan Kuantitatif,. Kualitatif dan $R \& D$ ). Bandung : CV. Alfabeta.

Suparlan. (2018). Filsafat Ilmu Pengetahuan, Persoalan Eksistensi Dan Hakikat Ilmu Pengetahuan. Yogyakarta: Ar-Ruzz Media.

Suriasumantri. (2000). Filsafat Ilmu Sebuah Pengantar Populer. Jakarta: Pustaka Sinar Harapan.

Susanto. (2015). Filsafat Ilmu: Suatu Kajian Dalam Dimensi Ontologis, Epistemologis, Dan Aksiologis. Jakarta: PT. Bumi Aksara.

Suwardi. (2017). Filsafat Ilmu Konsep Sejarah Dan Pengembangan Metode Ilmiah. Yogyakarta: Remaja Rosdakarya.

Umar. (2016). Konvergensi Agama Dan Sains Dalam Melacak Basis Ontologi Semesta: Tinjauan Hermeneutika Hadis Penciptaan. JURNAL THEOLOGIA, 27(1), 173-212.

Yazdi. (2003). Menghadirkan Cahaya Tuhan: Epistemologi Iluminasionis dalam Filsafat Islam. Bandung: Mizan. 